\title{
THEORY OF POLITENESS IN MODERN LINGUISTICS
}

\author{
Feruzakhon Ulugbekovna Mirxodjaeva
}

Senior Teacher, Department of Comparative Linguistics And Theory Of Translation, Faculty Of Foreign Philology, National University Of Uzbekistan Named After Mirzoulugbek, Uzbekistan

\section{ABSTRACT}

The article is devoted to the study of the features of the verbalization of the concept of politeness in modern English, namely, the consideration and systematization of the possible andthe acceptable repertoire of linguistic tools available to the speaker to create polite utterancesin relation to various situations of communication, which, in its turn, involves consideration of interdependence and interaction of the actual semantics of the statement and its pragmatic parameters in the formation of a common meaning statements.

KEYWORDS: - Politeness theory, politeness, semantics, concept, pragmatics.

\section{INTRODUCTION}

Politeness is a complex and multifaceted phenomenon that is an integral part of people's daily life and permeates all human interaction. The unrelenting interest in the study of this phenomenon on the part of representatives of different fields of knowledge testifies to the importance of this issue in human relationships in general and especially in intercultural interaction. Studies in the field of politeness from a pragmatic point of view were carried out already in the early 70s of the last century and go back to the works of R. Lakoff / Lakoff R., 1973 /, P. Brown and S. Levinson / Brown \& Levinson, 1978; 1987 / and J. Leech / Leech, 1983 /. Over the past decades, a large number of articles and monographs on this topic have appeared, including in different cultures / see. Literature / [1].

However, despite numerous publications, the analysis existing work in this area indicates lack of unity of views on what constitutes the phenomenon of politeness and what should be understood by this category, what is its nature and what are the mechanisms of its action indifferent linguocultures. Trying to describe the category of politeness as fully as possible, the researchers suggest different approaches, different learning models.

Politeness stands out as a separate issue in which specialists are interested in a number of humanities such as linguistics, sociology, psychology, 
CURRENT RESEARCH JOURNAL OF PHILOLOGICAL SCIENCES 2(9): 15-20,

September 2021

DOI: https://doi.org/10.37547/philological-crjps-02-09-04

ISSN 2767-3758

(C)2021 Master Journals

Crossref doi

gil Google

Accepted20 $0^{\text {th }}$ September, 2021 \& Published 25 $5^{\text {th }}$ September, 2021

ethnography, cultural studies, social anthropology, linguopragmatics, sociolinguistics, psycholinguistics, applied linguistics, etc. And this is no coincidence, since the category of politeness as multidimensional phenomenon can be considered only at an interdisciplinary level, and only joint efforts of scientists of related specialties can answer the question of what is communication in general, and, in particular, what constitutes politeness as its integral and especially significant part. The problem of politeness as a subject of scientific analysis is directly related to the culture of speech and speech etiquette, which traditionally receive a lot of attention. Speech etiquette is an integral part of the culture of communication. Among of numerous manifestations of culture, the culture of communication occupies an important, if not leading, place in the life of society, since communication has a unifying, influencing function in the life of people, in communication, the interaction of communication partners is realized to achieve both communicative and noncommunicative goals. It is obvious that communicate with the addressee in such a way as not to inflict damage to your speech. Politeness and etiquette fulfill this mission.

In a specific act of communication, the desire of the interlocutors to inflict the least "damage" on each other is manifested as the discrepancy between communicative (expressed) and denotative (real) truth, and the former is more pleasant for the interlocutor. This is achieved by neutralizing or increasing the assessment of the denotative situation, which is formulated as the following rule of etiquette: "in a conversation, try to maximize the position of the interlocutor in all parameters "/ Pocheptsov, 1981 /.

Etiquette is a philosophical and ethical concept. Etiquette is a certain system of norms, a set of rules of behavior, concerning the external manifestation of attitude towards people. The philosophical and ethical interpretation of etiquette is reduced to a system of prohibitions and permissions, including speech, existing in every given society, in a given environment, in a given collective. According to N.I. Formanovskaya, "the norms of speech etiquette permeates any speech act. Etiquette defines all our behavior. And what is meant by speech etiquette is used in the speech of each of us daily and repeatedly. Perhaps these are the most common expressions: wemany times a day we turn to someone, we greet our acquaintances and strangers, we say goodbye to people, we thank someone, we apologize to someone, we congratulate someone, we wish good luck to someone or make compliments, we condole with someone, sympathize ; we advise, ask, offer, invite, demand ...Speech etiquette is a class of speech acts with its own specific functions and speech intentions, outside of which and without which communication does not threaten to become successful "/ Formanovskaya, 2002: 14 /.

The close relationship between the category of politeness and speech the etiquette is obvious. However, despite this, it is advisable to separate the category of politeness from the concept of "speech etiquette", since the category of politeness does not applyonly to stable, regularly repeated ritualized formulas such as greeting, goodbye, gratitude, compliment, invitation, etc., but also to a wider circlevarious phenomena.Important to clarify this the question seems to be expressed by V.S. Khrakovsky opinion about that courtesy is optional addition to the mandatory etiquette treatment / Khrakovsky, 1980 /.

Researchers working within the framework of the theory of linguistic politeness have different approaches to certain aspects of the studied category, but they are all unanimous in defining politeness as a line of conduct aimed to maintain 
CURRENT RESEARCH JOURNAL OF PHILOLOGICAL SCIENCES 2(9): 15-20,

September 2021

DOI: https://doi.org/10.37547/philological-crjps-02-09-04

ISSN 2767-3758

(C)2021 Master Journals

Crossref doi

gil Google

Accepted20 $0^{\text {th }}$ September, 2021 \& Published 25 $5^{\text {th }}$ September, 2021

social harmony, and do not identify the concepts of "politeness" and "etiquette" (see, for example, Brown \& Levinson, 1994: 1, 51)Being directly related, these two phenomena do not cover each other, and the relationship between them can be defined as follows: not everything is polite, that is etiquette, but everything that is unethical, impolite / Formanovskaya, 1998 /. Etiquette behavior is considered in most works as a component of the phenomenon of politeness. As linguistic politeness theorists point out,"Politeness is rooted in interpersonal ritual communication "; both politeness and ritual behavior are based on "the control of any social group over internal and external aggression" in relations with other social groups / Brown \& Levinson, 1987 /. Butthe concepts of "politeness", "respect", "respect", "tact" are at a much higher social level, than just a set of rules. In addition, if etiquette is a set of communicative norms and rules, then politeness is a system of communication strategies and tactics used in real communication and aimed at achieving harmony and mutual understanding."Politeness includes anything that contributes to harmonious, conflict-free communication, despite the fact the fact that some of its elements may not be (at a certain stage or in a specific communicative situation)the norm fixed by etiquette "/ Larina, 2003: $17 /$.

According to N.I. Formanovskaya, the linguistic category of politeness refers to functional-semantic categories with pragmatic functions of expressing the speaker's attitude to the listener, to the importance of the case, to the situation as a whole. Acting as an ethical category, politeness can either demonstrate external norms of communication, decency of behavior, or signify a benevolent personal attitude towards the addressee. Polite behavior can manifest itself as sincerity, or it can be a mask, especially in role-based communication with unfamiliar partners / Formanovskaya, 2002
/.In the linguistic literature, there are a number of approaches to the problem under study.

Among the whole variety of concepts and interpretations of the category of politeness, the following most significant areas of research of this social and pragmatic category can be conditionally distinguished: the social-norm view, 'the conversational-maxim view,the face-saving view, orface-management view, the conversationalcontract view, and also post-classical theories, considering, along with politeness, the concept of impoliteness and including discursive or postmdiscursive approach , sociological (otherwise" interactional ")approach, the theory of social interaction ('relational work theory'), the rapport management theory, etc.Consider these theories and models of politeness in more detail below.

The subjunctive mood as one of the means implementations of the principle of politeness in English an equally important way to mitigate categorically utterances, along with modal means, serve as forms of the subjunctive (conditional) mood, representingevents as hypothetical, not existing in reality. For example, she took her things and a lot of mine as well.You just would not recognize the bedroom (I. Murdock). Thought about the role of the subjunctive mood in realization the principle of politeness was expressed by Yu. D. Apresyan in the article "Pragmatic information for an explanatory dictionary", wherehe writes that the differences between the statements "I ask you get out. "," I will ask you to get out. "," I would ask you to get out " and "I would ask you to come out." are not in the field of semanticstype, time, mood, and in the field of pragmatics and are reducedto differences in the degree of politeness: the subjunctive mood the most polite form of request, and the simple future is the most tough. In other respects, utterances are synonymous. / Apresyan, 1988: 27 / 
CURRENT RESEARCH JOURNAL OF PHILOLOGICAL SCIENCES 2(9): 15-20,

September 2021

DOI: https://doi.org/10.37547/philological-crjps-02-09-04

ISSN 2767-3758

(C)2021 Master Journals

Crossref do

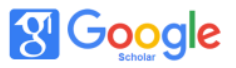

Accepted20 $0^{\text {th }}$ September, 2021 \& Published 25 $5^{\text {th }}$ September, 2021

Subjunctiveness in combination with modality, used in an informative statement, gives the speaker's speech a special intentional orientation. So, 'Could you be more specific? 'and' There's more in the pantry. Would you get it for me?'acquire the function of a request, while remaining informative in functional terms. These structures are so conventionalized that they are sometimes used withouta question mark 'Would you please explain'.Subjunctive verb of increasing degree

the politeness of the statement, since the conditional mood expresses presumptiveness, hypothetical from the side the speaker, which is absent in the verbs in the indicative inclination, and thus reduces the straightforwardness of the statement. The addressee is given the opportunity to choose, andthe speaker at the same time expresses doubt about the possibility or the addressee's desire to take an action. The subjunctive mood is widely used in statements containing a request. Questions with could and would, which act as distancing means and avoid straightforwardness of speech, sound more polite than with can and will, since they also express a greater share of doubt about the ability or desire of the addressee

take an action, as a result of which he is given even more choice. Thus, the degree of impact on the addressee is reduced.Let's compare:

'Can you help me to set up this projector?'

'Could you help me to set up this projector?' and

'Will you do some shopping for me?'

'Would you do some shopping for me?'

According to E.I.Belyaeva, the use of interrogative sentences that seem to move the desired situation into one of the possible worlds, gives the directive statement a less categorical character / Belyaeva, 1985 /.

Note that in theoretical English grammar language it is difficult to find a more controversial category than the subjunctive mood. This controversy is explained by a number of reasons, including the question of the status of modal verbs participating in the construction of analytical forms of the subjunctive mood.As you know, in English, auxiliary verbs involved in the formation of analytical forms are desemantized, which ensures their universal compatibility with all words of this class / Ivanova, Chakhoyan,1976: 164 /. However, this statement can hardly be extended to modal verbs in analytical forms in subjunctive mood.

So, if the verb to have has completely lost the meaning of possessiveness in perfect forms, then the verbs should, would, could, might, participating in the formation of analytical forms of the subjunctive mood, such connections with modal verbs proper have not lost. About this is evidenced by their use like the following:

(1) I demand that he should know the truth.

(2) She moved forward so that she could see everything better.

When analyzing such cases, it seems legitimate not talking about auxiliary verbs (in the accepted sense), but about the special function of modal verbs in the formation forms of the subjunctive mood. Here is what E.A.Zverevain this regard: "Performing the same syntactic function - the first member of a compound verb predicate, modal verbs act in two different functions withpoint of view of the direction of the modal expressed by them meaning. In their main, primary function, modal verbs express the relationship between the subject of the action and action: necessity, opportunity, or desirability actions for the subject. In the secondary function, modal verbs express the speaker's attitude to the content of everythingproposals in terms of the degree of its correspondence to reality "/ Zvereva, 1983: 84 /.

In the terminology of I. B. Khlebnikovasuch cases are "morphological options": they stand on the 
CURRENT RESEARCH JOURNAL OF PHILOLOGICAL SCIENCES 2(9): 15-20,

September 2021

DOI: https://doi.org/10.37547/philological-crjps-02-09-04

ISSN 2767-3758

(C2021 Master Journals

Crossref do

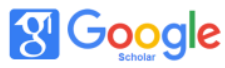

Accepted20 $0^{\text {th }}$ September, 2021 \& Published 25 $5^{\text {th }}$ September, 2021

periphery of the subjunctive mood and serve specific modal meanings that are included in the expression of the actions of the unrealized / Khlebnikova, 1971: 15/.

The ability to involve modal verbs in the system analytical forms of the subjunctive mood was due to their general meaning of the potentiality of action, itshypotheticalness, which can be represented by such particular values as should (must, should, ought),possibility (can - could), probability (may might) and others.

However, in the grammatical context of the subjunctive mood, these particular meanings recede into the background and the leading the function of the combinations "modal verb + infinitive" is precisely the expression of an unrealized action. At the boundaries between the primary, proper modal, and the secondary, grammatical, function of modal verbs in the analytical form are not clear enough, therefore we consider it necessary to dwell in more detail on the criteriatheir differentiation. The most important of these criteria is the temporal correlation of the content of the entire utterance. For verbsshould, would, could and might in the subjunctive mood is characterized by correlation with the present tense, despite their formal belonging to the pasttime. In this regard, noteworthy is the statement M.Dzhusa, who, firstly, names modal verbs in subjunctive "remote modals", emphasizing the weakening of their primary meaning, and, secondly, notes the specifics of their temporal correlation. As the author writes: “... The remote modals, should, would, could, might more often have unreal contemporary than real past meaning "/ Joos, 1968: 123 /. Indeed, the saying "You might be more laconic. " has nothing to do with the past, but serves as a hint to the interlocutor to be less verbose.

We find a similar statement by D. Koike, who notes that "... the conditional which is linked to the past is semantically oriented to the present coding time of the speech act. Thus, there is a conflict between the temporal frame and use of a mood which is not usuallyused in that frame". D. Koike goes further and characterizes the subjunctive mood as marked from the point of viewcourtesy form: "This disordering may be one reason for using the conditional in such contexts as a special, marked form denoting politeness "/ Koike, 1989: 193 /.

\section{Conclusion}

Overall, it can be said that the analytical forms of the subjunctive mood, built on the basis of modal verbs, play an important role in creating the expressive tonality of both an individual utterance and a dialogue inthe whole. They are directly involved in the implementation of the principle of politeness in such stimulating speech acts as advice, request, proposal.

\section{RefERENCES}

1. Е.Л.ЕрЗиняк (2018). ЛИНГВИСТИЧЕСКАЯ КАТЕГОРИЯ ВЕЖЛИВОСТИ: СЕМАНТИКА И ПРАГМАТИКА. ЕРЕВАН, ИздаТеЛЬство ЕГУ 2018-ст 65-68.

2. Ларина Т.В., Харлова М.Л. Невежливость и грубость в межличностном общении американцев // Вестник Новосиб. гос. унта. Серия: «Лингвистика и межкультурная коммуникация», т. 13, вып. 3. Новосибирск, 2015. - С. 34-42.

3. Беляева Е.И. Принцип вежливости в речевом общении // Иностранные языки в школе, 1985, № 2. - С. 3-10.

4. Беляева Е.И. Функциональносемантические поля модальности в английском и русском языках. Воронеж: Изд-во Воронеж. университета, 1985. 
CURRENT RESEARCH JOURNAL OF PHILOLOGICAL SCIENCES 2(9): 15-20,

September 2021

DOI: https://doi.org/10.37547/philological-crjps-02-09-04

ISSN 2767-3758

(C)2021 Master Journals

Crossref dof 81 Google

Accepted20th September, 2021 \& Published 25 ${ }^{\text {th }}$ September, 2021

5. Апресян Ю.Д. Прагматическая

информация для толкового словаря //

Прагматика и проблемы

интенсиональности. М.: Ин-т языкознания

АН СССР, 1988. - С. 7-44.

6. Апресян Ю.Д. Избранные труды. Том II.

Интегральное описание языка и

системная лексикография. М.: Языки русской культуры, 1995.

7. Формановская Н.И. Речевой этикет и культура общения. М.: Высшая школа, 1989. Формановская Н.И. Прагматика побуждения и логика языка // Русский язык за рубежом, № 5-6, 1994. - С. 34-40

8. Voinov, V. (2016). Politeness devices in the Tuvan language.

9. Koyama, T. (2001). Universals in perceived politeness: Comparison of native and nonnative speakers of English. TheUniversityofArizona.

10. Ismatulla, K., \& Clark, L. (1992). Uzbek: Language Competencies for Peace Corps Volunteers in Uzbekistan.

11. Rasuljanovna, I. N. (2019). THE PHENOMENON OF LACUNARITY AS THE LINGUACULTURAL ISSUE. PROSPECTS OF WORLD SCIENCE-2019, 226. 